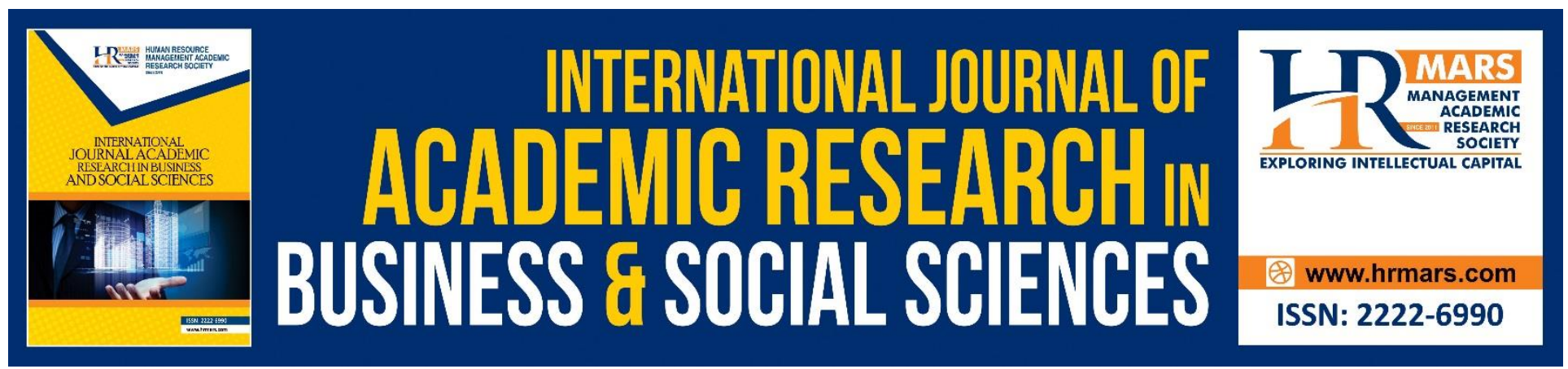

\title{
Principals' Instructional Leadership in Small School-A Preliminary Study
}

Nitce Isa Medina, Azlin Norhaini Mansor, Jamalul Lail Abdul Wahab, Sharmini Siva Vikaraman

To Link this Article: http://dx.doi.org/10.6007/IJARBSS/v8-i8/4623

DOI: $\quad 10.6007 /$ IJARBSS/v8-i8/4623

Received: 19 June 2018, Revised: 23 July 2018, Accepted: 29 July 2018

Published Online: 27 August 2018

In-Text Citation:

To Cite this Article:

Copyright: (C) 2018 The Author(s)

Published by Human Resource Management Academic Research Society (www.hrmars.com)

This article is published under the Creative Commons Attribution (CC BY 4.0) license. Anyone may reproduce, distribute, translate and create derivative works of this article (for both commercial and non-commercial purposes), subject to full attribution to the original publication and authors. The full terms of this license may be seen

at: http://creativecommons.org/licences/by/4.0/legalcode

Vol. 8, No. 8, August 2018, Pg. 674 - 685

http://hrmars.com/index.php/pages/detail/IJARBSS

JOURNAL HOMEPAGE

Full Terms \& Conditions of access and use can be found at http://hrmars.com/index.php/pages/detail/publication-ethics 


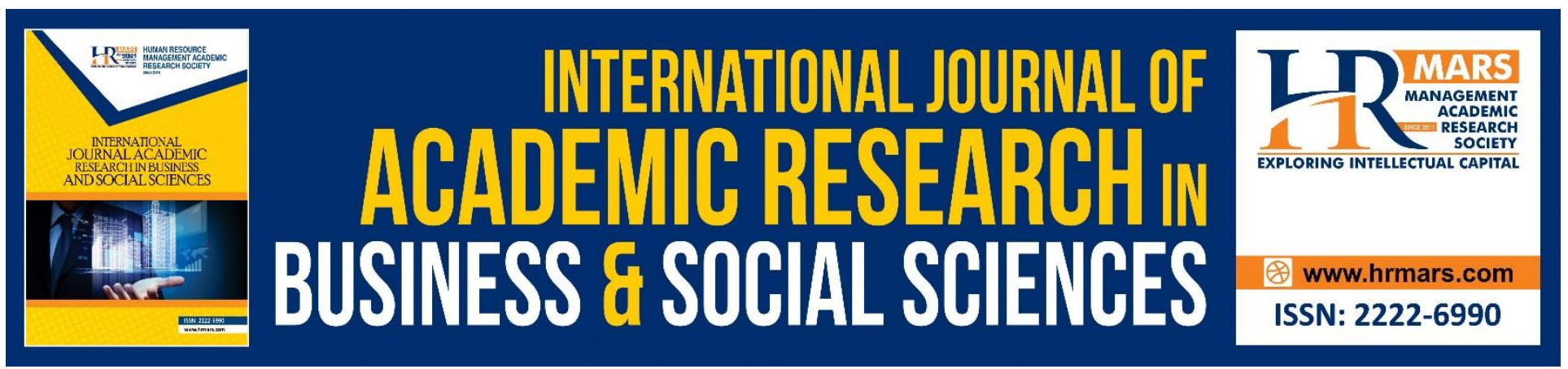

\title{
Principals' Instructional Leadership in Small School-A Preliminary Study
}

\author{
Nitce Isa Medina, Azlin Norhaini Mansor, Jamalul Lail Abdul Wahab, \\ Sharmini Siva Vikaraman \\ Universiti Kebangsaan Malaysia, Malaysia
}

\begin{abstract}
The challenges faced by principals in small schools are unique due to its context. Small schools which has less than 150 enrolments of students are mostly located in rural areas. Yet, educators are concerned about the ability of the principal to adapt to this context considering many limitations and multitasks at the same time. This paper discusses the principals' instructional leadership practices in three different types of small schools which are Sekolah Kebangsaan (SK), Sekolah Jenis Kebangsaan Cina (SJKC) and Sekolah Jenis Kebangsaan Tamil (SJKT) in Perak state. The purpose of this preliminary, quantitative study was to examine how their instructional leadership practices differ in these schools. Through the use of a cross-sectional survey, responses made by 92 teachers from nine schools were compared. The Principal Instructional Management Rating Scale (PIMRS) Teacher Short Form was used for data collection. Findings showed that principals' instructional leadership practices in this study is at moderate level. Although the principals' instructional leadership practices level is the lowest for SK principals, the findings also showed that there is no significant difference in principals' instructional leadership practices level among all schools. Nevertheless, the areas of significance identified by this study showed that despite all challenges, the principals from different types of schools are practicing instructional leadership at their best.
\end{abstract}

Keywords: Educational Leadership, Instructional Leadership, Principal, Rural, Small School

\section{Introduction}

Instructional leadership impact in Southeast Asia has become increasingly important (Hallinger \& Bryant, 2013) ever since it became the subject of research over the last three decades. As an instructional leader, school principals also need to face many challenges including the need to compete with the 21st century learning, resulting to the "leaders dilemma" (Adams, Raman Kutty, \& Zuliana, 2017). Thus, it is critical for a principal to understand the concept of leadership so they can be an efficient leader in school. To relate instructional leadership, the path-goal theory by House (1996) can be applied by the principals. This theory was designed to identify leader's practiced style as a motivation to get subordinate to accomplish goals. It also reinforces the idea that as a school leader, the principals must make sure that motivation plays an important part in how a principal and 
teacher interact. Positive interaction further brings about the intentions towards attaining school goals despite challenges.

Yet, empirical research into instructional leadership lacks similar levels of sensitivity especially to small school context. The complexity of small school is due to its location, challenges organizational, pedagogical and managerial (Smith \& Hudson, 2004) and specific limitations. High importance is given to effective teaching and management of small school student academic success despite the low number of students. In many cases, even the principals engage in classroom teaching. Nevertheless, the existence of small schools is meant to provide education for primary school students, in line with the 'Education for All' policy that has been implemented by United Nation, Educational, Scientific and Cultural Organization (UNESCO). The 'Education for All' framework was established in 2000, and many countries have made progress towards the goals. The implementation of the policy is in the needs to provide education to all children, although people in the most marginalized groups have continued to be denied opportunities for education over the decade (UNESCO, 2014).

Researchers world-wide who pay attention to small school context has argued on how to define it. Many defined small school as school that is not only small in size but located in rural area (Bloom, Thompson, Unterman, Herlihy, \& Payne, 2010; Blum, 2009; Clarke \& Wildy, 2006; Gardener \& Edington, 1982; Reeves, 2003; Southworth, 2012; Swift, 1984; Tuck, 2009). Most of the researchers agreed that the enrolment of students in small school are lesser than 200 (Ewington et al., 2008) or less than 100 (Bloom et al., 2010; Blum, 2009; Clarke \& Wildy, 2006; Hargreaves et al., 2017; Tuck, 2009). In Malaysia, The Ministry of Education has defined small school as school with under 150 enrolments of students (Marzita \& Arbain, 2013; Ministry of Education, 2007; Mohd Yusoff \& Sufean, 2013; Zakaria, 2016). Until March 2017, there are 2996 small schools in Malaysia, with 2058 are national primary school or Sekolah Kebangsaan (SK) Sekolah Kebangsaan (SK), 578 are vernacular Chinese primary school or Sekolah Jenis Kebangsaan Cina (SJKC) and 360 are vernacular Tamil primary school or Sekolah Jenis Kebangsaan Tamil (SJKT).

\section{Small School in Perak State}

There are 252 small schools in Perak state, which are mostly located in palm oil or rubber plantation, small town and traditional village. Like most small schools in other states in Malaysia, small schools in Perak state are divided into three different categories based on prominent races that reside in the location. The three categories are SK with mostly Malay community, SJKC with majority from Chinese community and SJKT with mostly Indian community. Some schools have emerged during the British era and are still maintaining their old building that appeared to be operating for decades.

Even though the schools are located in remote or rural areas, there is no doubt that the existence of small schools in these areas has been taken as an important organization that helps develop social network with the local community. Most principals from rural area schools in Perak state agreed that their school location is strategic, considering that the community can get better access to education (Zakaria et al., 2010). Clearly, small school is needed to be an accelerant in the community but there are doubts whether the school can carry the role because of its underperformed status (Ministry of Education, 2012; Zalika, Faridah, \& Mohamad Johdi, 2009) apart from the principal leadership factor that contributes to the status (Dolbasar, Shahril@Charil, \& Jamal@Nordin, 2013). In addition to that, majority of small schools in Perak state are academically 
INTERNATIONAL JOURNAL OF ACADEMIC RESEARCH IN BUSINESS AND SOCIAL SCIENCES

Vol. 8, No. 8, August 2018, E-ISSN: 2222-6990 @ 2018 HRMARS

underperformed with student's socioeconomic factors being stated as the biggest hindrance (Azlin Norhaini et al., 2016).

\section{Instructional Leadership in Small School}

Leadership in the context of small school is considered to be complex and need attention from researchers and policy makers (Clarke \& Wildy, 2006; Ewington et al., 2008). This is because there are multiple specific challenges (Catterson, 2017) compared to other school types that need to be faced by small school principal as an instructional leader (Clarke \& Stevens, 2014) whereby existing theories and concepts may not assist (Smith \& Hudson, 2004). Previous studies have reported that principals' instructional leadership practices in small school need to possess certain qualities as a school leader. Southworth (2012) in his finding noted that successful small school principal should be working extra hard, are positive people at all circumstances, team builders and players within small group of school employees, school improvers despite the size of the school and educational leaders. This is supported by a detailed investigation by Azlin Norhaini et al. (2016) that revealed most underperformed small schools in Perak state are lacking in leadership and management strategies which contributes to deficiency in motivation and pedagogy competencies among teachers. Perhaps the size and conditions of the school demands extra focus to the area of specific leadership structure (Catterson, 2017) or practice that can denote directly and effectively towards small school success and performance.

The principals in small schools face multiple task daily very similar to other school types despite leading a school of a small size. The term 'teaching principal' is used to describe the dual responsibility carried by most principal in small school whereby they need to handle administrative tasks as a school leader and classroom teaching duties at the same time (Clarke \& Stevens, 2014). Small school condition also leads to small number of teachers, leaving the principal with no choice but to become one of the teaching team member to make sure teaching and learning runs smoothly. While trying to cope with this situation, it is learnt that instructional leadership is enacted by "teaching principals" in small rural schools who perceive that their dual role enriches their relationships with others, lends credibility to their teaching or leadership efforts and to structures within contexts that are both challenging and highly rewarding (Wallin \& Newton, 2013).

Due to small number of students, there are small schools that practice 'combined class system'. This is a system whereby for example, the Primary Two students would be combined with Primary Three, and Primary Four with Primary Five students, creating a 'multi-age or multi-grade classroom'. Practicing 'combined class system' will cause teachers to adjust their pedagogy to suit not only different student academic level but also age. It is also a common practice in small, rural schools for few teachers to cover many subjects and then be engaged in after school programs (Smit, Hyry-Beihammer, \& Raggl, 2015) subsequently adding more instructional burden to teachers and the "teaching principal".

There is also a challenge to maintain experience teachers in small school due to high possibility that the teachers be offered better opportunity in urban schools (Blum, 2009; Collins, 1999; Gardener \& Edington, 1982; Lemke, 1994; Lowe, 2006; Mohd Yusoff \& Sufean, 2013; Reeves, 2003; Swift, 1984; Tuck, 2009) or brain drained to better positions in bigger organizations. In addition to that, there is evidence that the role of conflict in small school principal causing the principal to stay for short period of time (Ewington et al., 2008) resulting with frequent turnover of principal and teachers in small school from time to time. 
INTERNATIONAL JOURNAL OF ACADEMIC RESEARCH IN BUSINESS AND SOCIAL SCIENCES

Vol. 8, No. 8, August 2018, E-ISSN: 2222-6990 @ 2018 HRMARS

Whilst extensive research has been carried out on principals' instructional leadership, there has been little data on principals' instructional leadership practices in small school. Thus, this paper will provide an insight into the small school principals' instructional leadership practices in Perak state. The study under discussion aims to answer the following research questions:

Q1: What are the levels of small school principals' instructional leadership practices in Perak state?

Q2: Are there any significant differences between the small school principals' instructional leadership practices level among SK, SJKC and SJKT in Perak state?

Q3: What is the most practiced dimension in instructional leadership by small school principal in SK, SJKC and SJKT in Perak state?

\section{Conceptual Framework}

The conceptual framework that identified the principals' instructional leadership practices in this study are stated in Figure 1.

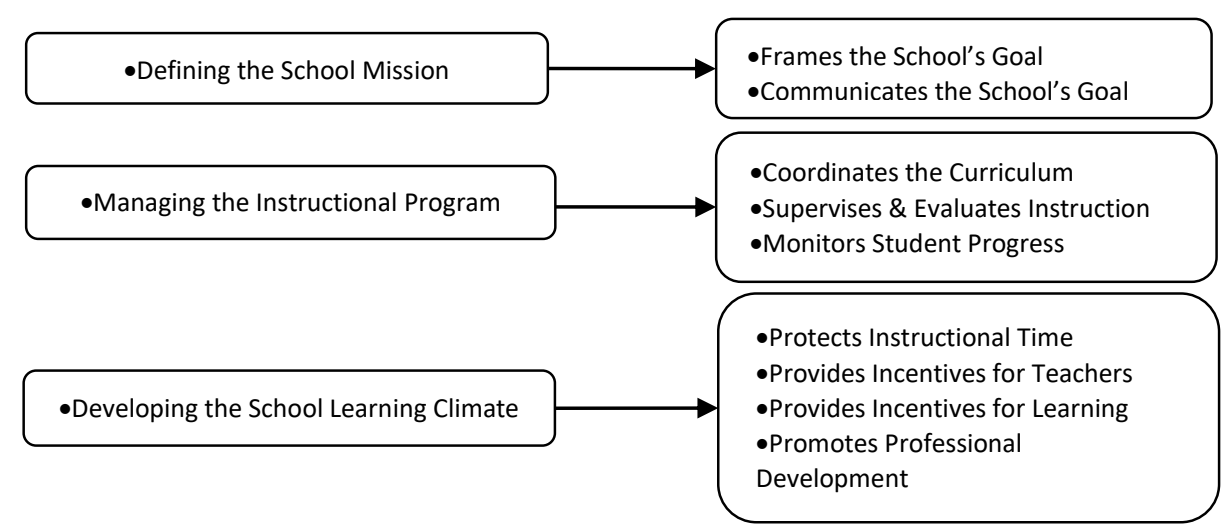

Fig.1. Principals' Instructional Leadership Practices Conceptual Framework

In Figure 1, the principals' instructional leadership practices are referred by incorporating three dimensions based upon the conceptual framework suggested by Hallinger, Wang, Chen, \& Liare (2015) and Hallinger, Wang, \& Chen (2013). The first dimension which is 'defining the school mission' refers to the principals' role in determining the areas and resources in which the school will focus on. It consists of two sub-dimensions which are 'frames the school's goal' and 'communicates the school's goal'. The second dimension, 'managing the instructional program' focuses on the coordination and control of instruction and curriculum.

Consists of three sub-dimensions, the second dimension is characterized by 'coordinates the curriculum', 'supervises and evaluates instruction' and 'monitors student progress'. The last dimension, 'developing the school learning climate', conforms the notion that successful schools need the development of high standards and expectations that rewards continuous learning and improvement. The last dimension is defined with the most number of sub-dimensions, that are 'protects instructional time', 'provides incentives for teachers', 'provides incentives for learning', 'promotes profesional development' and lastly 'maintains high visibility'. 
INTERNATIONAL JOURNAL OF ACADEMIC RESEARCH IN BUSINESS AND SOCIAL SCIENCES

Vol. 8, No. 8, August 2018, E-ISSN: 2222-6990 @ 2018 HRMARS

\section{Methodology}

A quantitative cross-sectional survey was used in this study involving small schools in Perak state. Nine small primary schools which consist of three types namely SK (National), SJKC (Vernacular Chinese) and SJKT (Vernacular Tamil) were randomly selected. All schools involved are located in rural area.

A comparison was done between the schools, with 92 teachers participating as respondents. All teachers were assigned to fill up a set of pencil and paper questionnaire each. The principals' instructional leadership practices were measured using the PIMRS Teacher Short Form which served as an effective instrument for the data collection with high standard reliability and internal validity (Hallinger \& Murphy, 2013; Hallinger et al., 2015). Data were gathered using a five-point Likert scale in the questionnaires. Teachers were asked to what extent they agree or disagree with the items presented in the instruments. The items that represented individual factors were then subjected to a reliability analysis while the rest of the data were analyzed using the SPSS software.

\section{Findings}

There were nine small schools with a total of 92 teachers involved in this study. All teachers in the small schools selected were respondents for this survey. As shown in Table 1 below, of the 92 teachers who participated in this survey, 30.4 percent (28) of them were male, and 69.6 percent (64) of them were female.

Table. 1. Respondent's Demographic

\begin{tabular}{llll}
\hline & & $(\mathrm{n}=92)$ & $\%$ \\
\hline School Type & SK & 31 & 33.69 \\
& SJKC & 30 & 32.60 \\
& SJKT & 31 & 33.69 \\
\multirow{4}{*}{ Gender } & & & \\
& Male & 28 & 30.43 \\
& Female & 64 & 69.57 \\
\hline
\end{tabular}

\section{Instructional Leadership Practices}

Table 2 shows the level of the principals' instructional leadership practices in three schools. The mean scores for all principals showed that their instructional leadership practices was at moderate level. The instructional leadership practice for SK principal is the lowest $(M=3.69, S D=.59)$ compared to SJKC (M=3.95, SD=.35) and SJKT $(M=3.95, S D=.57)$. The highest dimension mean shown is 'defining the school mission' by SJKT principal $(M=4.12, S D=.77)$ whereas the lowest dimension mean shown is 'developing the school learning climate' by SK principal (M=3.63, SD=.64). 
INTERNATIONAL JOURNAL OF ACADEMIC RESEARCH IN BUSINESS AND SOCIAL SCIENCES Vol. 8, No. 8, August 2018, E-ISSN: 2222-6990 @ 2018 HRMARS

Table. 2. Comparison on Means and Standard Deviations in Dimension of Instructional Leadership

\begin{tabular}{|c|c|c|c|c|c|c|}
\hline $\begin{array}{l}\text { Dimension of Instructional } \\
\text { Leadership }\end{array}$ & $\begin{array}{l}\text { SK } \\
\text { Mean }\end{array}$ & SD & $\begin{array}{l}\text { SJKC } \\
\text { Mean }\end{array}$ & SD & $\begin{array}{l}\text { SJKT } \\
\text { Mean }\end{array}$ & SD \\
\hline Defining the school mission & 3.83 & .68 & 4.02 & .36 & 4.12 & .77 \\
\hline $\begin{array}{l}\text { Managing the instructional } \\
\text { program }\end{array}$ & 3.65 & .57 & 3.91 & .45 & 4.05 & .61 \\
\hline $\begin{array}{l}\text { Developing the school learning } \\
\text { climate }\end{array}$ & 3.63 & .64 & 3.94 & .41 & 3.82 & .57 \\
\hline Overall & 3.69 & .59 & 3.95 & .35 & 3.95 & .57 \\
\hline
\end{tabular}

\section{Defining the School Mission}

The first dimension from instructional leadership conceptual framework shown in Figure 1 is 'defining the school mission'. As shown in Table 3, mean scores showed moderate level for SK principal $(M=3,83, S D=.68)$ but high level for SJKC principal $(M=4.02, S D=.36)$ and SJKT principal $(\mathrm{M}=4.12, \mathrm{SD}=.77)$. It was found that the lowest and highest sub-dimension mean comes from 'frames the school's goals' sub-dimension. The lowest mean for sub-dimension shown by SK principal $(M=3.82, S D=.69)$ whereas the highest sub-dimension mean is shown by SJKT principal $(M=4.15$, $\mathrm{SD}=.75)$.

Table. 3. Comparison of Means and Standard Deviations in Defining the School Mission Dimension

\begin{tabular}{lllllll} 
& SK & \multicolumn{3}{c}{ SJKC } & \multicolumn{3}{c}{ SJKT } \\
Defining the school mission & Mean & SD & Mean & SD & Mean & SD \\
\hline Frames the school's goals & 3.82 & .69 & 3.98 & .35 & 4.15 & .75 \\
Communicates school's goals & 3.85 & .73 & 4.06 & .46 & 4.09 & .86 \\
Overall & 3.83 & .68 & 4.02 & .36 & 4.12 & .77 \\
\hline
\end{tabular}

\section{Managing the instructional program}

As shown in Table 4, the mean scores for second dimension 'managing the instructional program' for both SK principal $(M=3.65, S D=.57)$ and SJKC principal $(M=3.91, S D=.45)$ are at moderate level. For this dimension, it shows that SJKT principal has high level of 'managing the instructional program' with a mean score of $(M=4.05, S D=.61)$ compared to their counterparts in other types of schools. It was found that the highest mean for sub-dimension is 'supervises and evaluate instruction' by SJKT principal ( $M=4.22, \mathrm{SD}=.84)$. Whereas, the lowest sub-dimension mean is 'monitors student progress' by SK principal with (M=3.50, SD=.54). 
INTERNATIONAL JOURNAL OF ACADEMIC RESEARCH IN BUSINESS AND SOCIAL SCIENCES

Vol. 8, No. 8, August 2018, E-ISSN: 2222-6990 @ 2018 HRMARS

Table. 4. Comparison of Means and Standard Deviations in Developing the Managing the Instructional Program Dimension

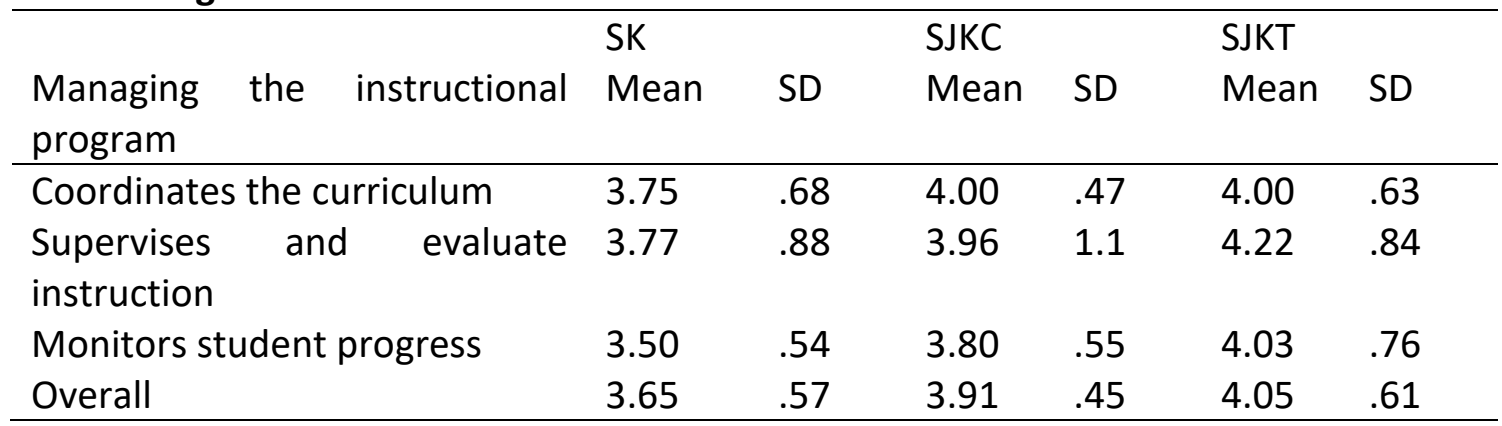

\section{Developing the school learning climate}

The third dimension from the instructional leadership conceptual framework shown is 'developing the school learning climate'. As shown in Table 5, the mean scores for principals from three types of school are at moderate level. The highest mean shown by SJKC principal (M=3.94, $\mathrm{SD}=.41)$, followed by SJKT principal $(M=3.82, S D=.57)$ and lastly SK principal $(M=3.63, S D=.64)$. The highest sub-dimension mean score shown for this dimension is 'promotes professional development' by SJKC principal $(M=4.13, S D=.41)$, whereas the lowest sub dimension mean shown is 'provides incentives for teachers' by SK principal (M=3.40, SD=.77).

Table. 5. Comparison of Means and Standard Deviations in Developing the School Learning Climate Dimension

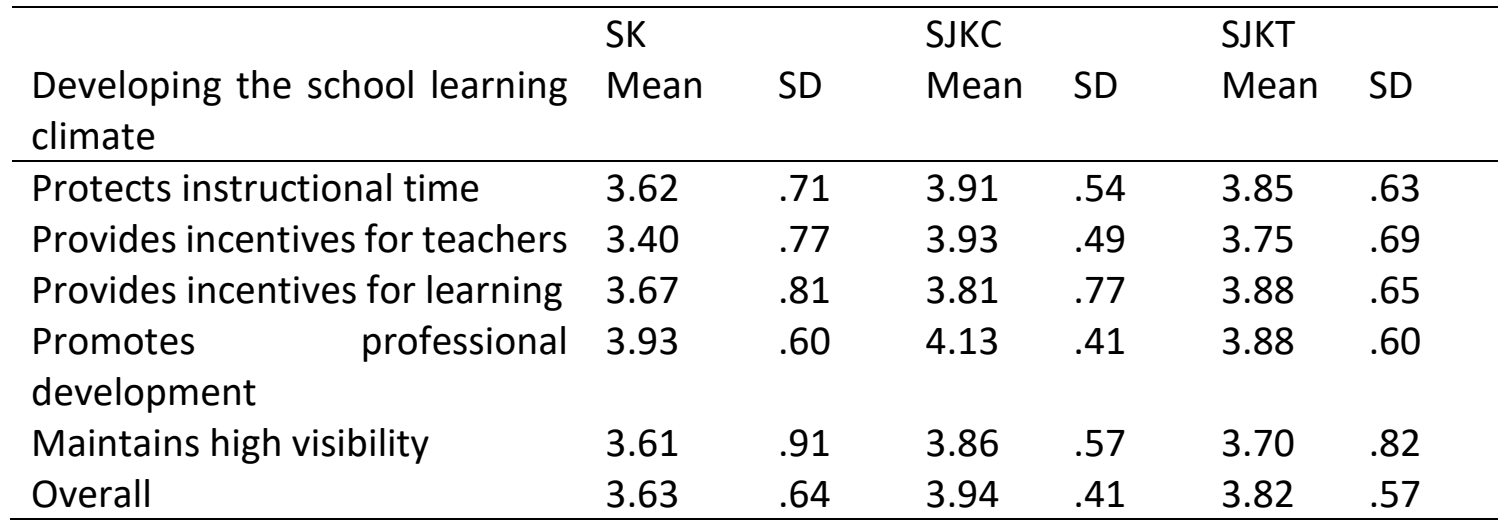

A one-way analysis of variance (ANOVA) was conducted to explore the impact of the principals' instructional leadership level as shown in Table 6 below. Even though there are differences of mean for principals' instructional leadership levels, there was no statistically difference at the $p<.05$ level in instructional leadership scores. The magnitude of the differences in the means was very small (eta squared=0.24) based on (Cohen, 1988). 
INTERNATIONAL JOURNAL OF ACADEMIC RESEARCH IN BUSINESS AND SOCIAL SCIENCES Vol. 8, No. 8, August 2018, E-ISSN: 2222-6990 @ 2018 HRMARS

Table. 6. ANOVA table of Principal Instructional Leadership Practices

\begin{tabular}{|c|c|c|c|c|c|}
\hline & $\begin{array}{l}\text { Sum } \\
\text { Squares }\end{array}$ & of $\mathrm{df}$ & $\begin{array}{l}\text { Mean } \\
\text { Squares }\end{array}$ & $F$ & Sig. \\
\hline Between & 1.44 & 2 & .72 & 2.66 & .075 \\
\hline \multicolumn{6}{|l|}{ Groups } \\
\hline Within Groups & 24.22 & 89 & .27 & & \\
\hline Total & 25.67 & 91 & & & \\
\hline
\end{tabular}

\section{Discussion and Conclusion}

The purpose of this study was to investigate small school principal's instructional leadership practices in Perak state. The small schools are categorized into three different types; SK (National), SJKC (Vernacular Chinese) and SJKT (Vernacular Tamil). There are nine schools and 92 respondents who were involved in this cross-sectional survey using PIMRS Teacher Short Form as instrument.

Results showed that overall principals' instructional leadership practice was at moderate level. It means that principals in this study played an important role as instructional leader despite the challenges they are facing while leading small size schools. The findings support the path-goal theory by House (1996) that states leader's style precisely acts as a motivator to get teachers to achieve school goals. Although there are differences of mean for principals' instructional leadership levels, there was no statistically difference in instructional leadership practices scores. This proves that despite the differences in culture and language that exist according to different type of schools, all principals are creating a consensus and clear academic mission while implementing the 'Education for All' policy.

Small school principals in Perak state practicing instructional leadership conforms the success of small school principal qualities that is to be equally effective as an educational leader (Southworth, 2012) despite the size of the school. It shows that small schools principal can provide facilities that assist teachers in many ways. For example, on-going teacher trainings, cost and funding management in teaching and learning, communication and counselling skills, small classroom teaching skills and school infrastructure sustenance. These findings also supported the views on qualified principals who focus on instructional leadership practices under challenging contextual conditions (Goldring, Huff, May, \& Camburn, 2008).

There are three dimensions stated in instructional leadership conceptual framework in this study based on Hallinger et al. (2015) that are 'defining the school mission', 'managing the instructional program' and 'developing the school learning climate'. The result for first dimension showed moderate level for SK principal but high level for SJKC principal and SJKT principal. It was found that the lowest and highest sub-dimension mean comes from the same sub-dimension which is 'frames the school's goals'. Setting goals and directions serves as a core practice and central purposes for any principal who wishes to become a successful instructional leader (Hallinger, Leithwood, \& Heck, 2010; Sun \& Leithwood, 2015) thus supporting the practice by SJKC and SJKT principal as an instructional leader. The school's goal served as a tool for the principal to reach the school target especially in academic achievement. It is suggested that the SK principal in small school to pay great attention to school goal and mission in order to improve their instructional leadership as being practised by SJKC and SJKT principals.

Result for second dimension which is 'managing the instructional program' for both SK principal and SJKC principal are at moderate level. For this dimension, it shows that SJKT principal has higher level of 'managing the instructional program' mean score compared to their counterparts in 
other types of schools. It was found that the highest sub-dimension mean is 'supervises and evaluate instruction' by SJKT principal. It is suggested for principal in small school to take advantages as a teaching principal to empower teaching and learning as they have direct access to their student academic performance. Being an instructional leader in small school also allows them to directly improve the quality of teaching with the opportunity of being a teaching principal. Having dual roles as both teachers and principals will increase principal's ability to provide instructional leadership, apart from enable the principal to maintain clear focus on the need of the student (Wallin \& Newton, 2013), thus increasing the principals' instructional leadership practice.

The third dimension from the instructional leadership conceptual framework shown is 'developing the school learning climate'. Mean scores for principals from three types of school are at moderate level. The highest sub-dimension mean shown for this dimension is 'promotes professional development' by SJKC principal whereas the lowest sub dimension mean shown is 'provides incentives for teachers' by SK principal. The findings suggest that the school learning climate in small school seem to be closely related to the teachers. Thus, it is suggested that principal in small school to focus on human resource which is the teachers and empowers them. Empowering the teachers can be done by fostering teacher's ownership to the school and recognising the teacher's pedagogy needs. More professional development for teachers need to be held so collaboration between principal and teachers in teaching and learning can be improved, leading to better student academic achievement. By giving adequate learning climate support to the teachers, it is hope that the deficiency in motivation and competencies among teachers as stated by (Azlin Norhaini et al., 2016) can be overcome.

Finally, the finding in this study can be interpreted with regards of the context stated. Findings in this study is limited to selected small schools in Perak state. More research is needed in order to get better understanding about principal instructional leadership in small school context, especially in other states. Recognizing this finding will provide a strong foundation for small school principals to meet the high expectations of teachers, students and the community in small school. The preparatory program such as the National Profesional Qualification for Educational Leaders (NPQEL) conducted by the Institut Aminuddin Baki under Ministry of Education should not only introduce future principal to research-based leadership strategies but to develop the ability to enact future principal with unique school and community context such as small school.

Despite challenges, small schools do provide ample opportunities like teacher empowerment and personal connection. Opportunities should be used as strength in handling challenges. Further research in small school context may identify factors that are affecting principals' instructional leadership dimensions in preference for the leadership practices.

\section{Corresponding Author}

Name: Azlin Norhaini Mansor

Affiliation: Faculty of Education, Universiti Kebangsaan Malaysia

Country: Malaysia

Email ID: azlinmansor@ukm.edu.my

Address: Faculty of Education, Universiti Kebangsaan Malaysia, 43600 UKM Bangi, Selangor, Malaysia. 
INTERNATIONAL JOURNAL OF ACADEMIC RESEARCH IN BUSINESS AND SOCIAL SCIENCES

Vol. 8, No. 8, August 2018, E-ISSN: 2222-6990 @ 2018 HRMARS

\section{References}

Adams, D., Kutty, G. R., \& Zuliana Mohd Zabidi. (2017). Educational Leadership for the 21st Century. International Online Journal of Educational Leadership, 1(1), 1-4. https://doi.org/https://doi.org/10.22452//ioejl.vol1no1.1

Bloom, H. S., Thompson, S. L., Unterman, R., Herlihy, C., \& Payne, C. F. (2010). Transforming the High School Experience. How the New York City's New Small Schools are Boosting Student Achievement and Graduation Rates. Retrieved from www.mdrc.org.

Blum, N. (2009). Small NGO schools in India: Implications for access and innovation Nicole Blum Institute of Education, University of London, UK, 39, 235-248.

Catterson, F. M. (2017). Small Primary School Leadership Structures: Challenges and Evolution (Doctoral dissertation, School of Education).

Clarke, S., \& Stevens, E. M. (2014). Sustainable leadership in small rural schools : Selected Australian vignettes Sustainable Leadership in Small Rural Schools : Selected Australian Vignettes Abstract, (April). https://doi.org/10.1007/s10833-008-9076-8

Clarke, S., \& Wildy, H. (2006). Context counts: Viewing small school leadership from the inside out. https://doi.org/10.1108/09578230410554061

Cohen, J. (1988). Statistical power analysis for the behavioral sciences. Statistical Power Analysis for the Behavioral Sciences. https://doi.org/10.1234/12345678

Collins, T. (1999). Attracting and Retaining Teachers in Rural Areas. ERIC Clearinghouse on Rural Education and Small Schools, 1-7.

Dolbasar Kasan, Shahril@Charil Marzuki, \& Jamal@Nordin Yunus. (2013). Pelaksanaan Perancangan Strategik dan Faktor Penyumbang terhadap Keberkesanan Sekolah di Sekolah Kurang Murid di Malaysia. Management Research Journal, 2(1), 1-18.

Ewington, J., Mulford, B., Kendall, D., Edmunds, B., Kendall, L., \& Silins, H. (2008). Successful school principalship in small schools. https://doi.org/10.1108/09578230810895483

Goldring, E., Huff, J., May, H., \& Camburn, E. (2008). School context and individual characteristics: What influences principal practice? Journal of Educational Administration. https://doi.org/10.1108/09578230810869275

Hallinger, P., \& Bryant, D. A. (2013). Accelerating knowledge production on educational leadership and management in East Asia: a strategic analysis. School Leadership \& Management. https://doi.org/10.1080/13632434.2013.773884

Hallinger, P., Leithwood, K. A., \& Heck, R. H. (2010). Leadership: Instructional. In P. Peterson, E. Baker, \& B. McGraw (Eds.), International Encyclopedia of Education (pp. 18-25). Elsevier Ltd.

Hallinger, P., \& Murphy, J. (2013). Assessing the Instructional Management Behavior of Principals, 86(2), 217-247.

Hallinger, P., Wang, W. C., \& Chen, C. W. (2013). Assessing the Measurement Properties of the Principal Instructional Management Rating Scale: A Meta-Analysis of Reliability Studies. Educational Administration Quarterly. https://doi.org/10.1177/0013161X12468149

Hallinger, P., Wang, W. C., Chen, C. W., \& Liare, D. (2015). Assessing instructional leadership with the principal instructional management rating scale. https://doi.org/10.1007/978-3-319-15533-3

Hargreaves, L., Comber, C., Galton, M. (2017). The National Curriculum : Can Small Schools Deliver? Confidence and Competence Levels of Teachers in Small Rural Primary Schools Linked references are available on JSTOR for this article: The National Curriculum : can small schools deliver ? Confidence , 22(1), 89-99. 
INTERNATIONAL JOURNAL OF ACADEMIC RESEARCH IN BUSINESS AND SOCIAL SCIENCES

Vol. 8, No. 8, August 2018, E-ISSN: 2222-6990 @ 2018 HRMARS

House, R. J. (1996). Path-goal Theory of Leadership: Lessons, Legacy and a Reformulated Theory. The Leadership Quarterly, 7(3), 323-352.

Lemke, J. (1994). Teacher Induction in Rural and Small School Districts. In National Conference of the American Council on Rural Special Education. Austin, Texas.

Lowe, J. M. (2006). Rural Education: Attracting and Retaining Teachers in Small Schools. The Rural Educator, 27.

Bakar, M. A. \& Pinni, A. (2013). Amalan Terbaik Pengurusan dan Kepimpinan Sekolah Kurang Murid (SKM). Jurnal Pengurusan Dan Kepimpinan Pendidikan, 26(2), 1-25.

Ministry of Education. (2007). Laporan Kajian Kepimpinan Guru Besar di Sekolah Rendah.

Ministry of Education. (2012). Laporan Awal Pelan Pembangunan Pendidikan Malaysia.

Nor, M. Y. M. \& Hussin, S. (2013). Demokrasi Pendidikan-Dilema Sekolah Kecil dan Sekolah Berpusat. Kuala Lumpur: Penerbit Universiti Malaya.

Reeves, C. (2003). Implementing the No Child Left Behind Act: Implications for Rural Schools and Districts. Retrieved from www.ncrel.org

Smit, R., Hyry-Beihammer, E. K., \& Raggl, A. (2015). Teaching and learning in small, rural schools in four European countries: Introduction and synthesis of mixed-/multi-age approaches. International Journal of Educational Research. https://doi.org/10.1016/j.ijer.2015.04.007

Smith, P., \& Hudson, B. (2004). Small Schools Meeting the Challenge: An Investigative Survey of Small Schools in County Durham. Scottish Educational Review, 36(1), 35-44.

Southworth, G. (2012). Lessons from Successful Leadership in Small School. In P. Leithwood, Kenneth A., Hallinger (Ed.), Second International Handbook of Educational Leadership and Administration (pp. 451-484). SPRINGER.

Sun, J., \& Leithwood, K. (2015). Direction-setting school leadership practices: a meta-analytical review of evidence about their influence. School Effectiveness and School Improvement. https://doi.org/10.1080/09243453.2015.1005106

Swift, D. (1984). Finding and Keeping Teachers: Strategies for Small Schools.

Tuck, A. (2009). Small school challenges: Learning lessons from small school headteachers.

UNESCO. (2014). EFA Global Monitoring Report.

Wallin, D. \& Newton, P. (2013). Instructional Leadership of the Rural Teaching Principal : Double the Trouble or Twice the Fun?, 41(2), 19-32.

Zakaria, O. (2016). Kepimpinan Instruksional Guru Besar di Sekolah Kurang Murid. University of Malaya. 